Pakistan Journal of Education

Vol.36, No.3, 2019, 39-50

\title{
A Critical Analysis of Research Scholar Expectations in Higher Education
}

\author{
Saddaf Ayub* \\ Muhammad Saeed Khan ${ }^{* *}$
}

\begin{abstract}
The study was designed to examine critical analysis of research scholar expectations in higher education at UOH. Objectives of the study were to find out recent scholar's expectations from university, to explore the social status of enrolling in higher education, to assess the educational preferences and skills and to analyze the economic status of research scholars.101 students of M. Phil program and 15 students of the Ph.D program from different departments (education, agriculture, environmental, mathematics, forestry, management, microbiology) were chosen as the sample of the study. A questionnaire was used for collection of data from the respondent. The questionnaire consisted of 22 items which was further divided into four sections. The first section of the questionnaire consists of the educational preferences and skill of scholar, the second section consists of social status about the scholars, the third section consists of the economic status of the scholars and the fourth section consist of expectations of the scholar. The study was quantitative and co-relational design was used. The researcher personally collected data from the departments of the University of Haripur through a questionnaire. For data analysis, multiple regressions were computed by SPSS. Multiple regression was used as a set of variables were used each of which correlates to some extent with a criterion variable for which we like to predict values. It was found that the graduates other than $\mathrm{UOH}$ as an independent variable (educational preferences and skills) contributes the most in explaining more expectation for research.
\end{abstract}

Keywords: research scholar, higher education.

\footnotetext{
*Assistant Professor, University of Haripur.Email:missraja@uoh.edu.pk

${ }^{* *}$ Assistant professor, Department of Education, University of Haripur. saeedaga03@gmail.com
} 


\section{Introduction}

Education is not for only to earn money, its basic aim is cognitive development which is directly related with mind. Education is very important for the development of nation and also for the development of the society. Rehman and Uddin (2009) stated that government has the responsibility to provide education and manage national properties. Also, higher education is necessary for community development. Byrne and Flood (2005) stated that higher education is about to command on a specific area. Persons who receive higher education they have to explore the opportunity to improve their career and to give a better life to their families. Higher education plays a significant role in a career development of a person. Higher education built a person to face the challenges which occur in their practical life and make them strong to adopt changing which are happening in society. Students have high expectation relating to their university career and these are very critical if they were developing and improve the engagement and learning experience for both faculty members and pupils. Teacher should know the needs of the students in higher education. Voss and Gruber (2007) stated that undergraduate student's expectations of university have an effect on student learning and their achievement and consummation in the higher education. But, these expectations cannot be genuine if higher education is not aware of student's expectations. Where these expectations were not fulfilled, students may discourage, with draw themselves or not actively engage their self in their program of study. Objectives of the study were to find out recent scholar's expectations from university, to explore the social status of enrolling in higher education, to assess the educational preferences and skills and to analyze the economic status of research scholars.

\section{Review of literature}

Sivakumar and Sarvalingam (2010) stated that education is one of the basic needs for human development and to escape from poverty. It is essential for the development of nation and society. Rahman and Uddin (2009) stated that government have the responsibility to provide the education and manage the national resources. Brennan and Teichler (2008) stated that higher education is important for social and economic impacts in society. Thus, governments and society have a vested interest in ensuring a constant flow of students in higher education. 
Briukhanov, Kiselev, Timchenko and Vdovin (2010) stated that every year many students go to developed countries to peruse high quality of higher education. It has the negative impact on the economy of our country as the large amount of money has been spent outside the country to peruse high quality of education. It was advised the local universities must provide facilities to local students and attract them to pursue education there and also foreign must encourage too came to Pakistan to get higher education. In order to attract local students there is need to understand the importance of quality in education.

Mohanthy (2000) stated that education is the basic need of every civilization. The social, scientific and technological development of the country depends upon the quality education system. Quality of education provided in the country effects human resource development of that country. Quality higher education is a base for socio economic and cultural development of the country. The purpose of higher education has deeper meaning and objectives, not only to convey information in certain branches of knowledge. The purpose can be multidimensional and may be called as personal, social, economic, and cultural.

Rao (2003) expressed that through higher education, one has to prepare the individual in universities who can perform in current and economic development of the society. The applicability of standards of market financial matters to the universities arrangement of all nations have made new setting for higher education. It was stated that students, the future subjects of the nation, must to be prepared for democracy, its value and standards with the goal that they will have feeling of equity which is favorable for the improvement of national integration particularly in the specific situation of developing countries which are endeavoring to develop a structure of democratic living. Walker (2008) stated that student's expectations were measured by understanding three big types i.e. contents, school staff and scores. The study explained that responses of students were diverted among the three categories mentioned above i.e. content that is considered in universities for career skills. It was the need of whole college life and life skills, that are beneficial for all aspects of educational career. Ginns (2007) stated that the students argue that learning is not directly related with the content and the teacher also, student learning was not always on the bases of their scores. It is need to understand that student assessment of teaching is considered one of the important research literature.

Akareem and Hussain (2012) find out the student characteristics effect the perception of higher education quality, like exciting position in 
society, socio economic background etc. There are limited studies who measured the degree that which type of student's characteristics effect the perception of higher education quality. Semela (2011) stated that every nation must transform itself to develop its economy and complete effectively in the modern world. The modern world faces many challenges that are very complex in nature and education is only source which will provide solution to these challenges. An efficient higher education system in the developing countries improve their economic development and it also, improves others area like education and training of business employees, improving qualities of leader, develop the conducive learning environment, and improve academic and educational activities.

Wolff (2002) stated that a number of research studies has investigated the relation between the teaching pedagogy and the learning environment in more depth. Students expected that learning environment in the higher institutions must meet clear bench marks across four areas: instrumental, organizational, interpersonal, and academic. If the institution was failed in providing the learning environment which was the expected by the students, it appeals to be seen as failing in its mandate. Students aggressively took stances on failures of their expectations due to interpersonal skill in learning environment of the institution.

Brew and Lucas (2009) stated that possible supervisors may be allotted to students as right on time as feasible for research projects, to enable them to work with you on developing a practical research project plan. It is argued that the presence of researcher in the classroom encourages educating and learning process. Why two different type of human activity, one proposed to examine the other, associate and mediate one another? Cultural-historical activity theory in which the framework for understanding the learning opportunities provided by the researcher to student when he is in the class. According to the theory and concept of learning, the presence of the researcher in the class is very important. Hoodbhoy (2009) stated that Pakistan is a developing country which face the uncertainty of political and economic growth. This uncertainty due to terrorism has effected all sectors including education in the country. The progress in the higher education is very slow on the country. After partition in 1947, Pakistan had only one public university which is in Punjab University in Lahore. In the last three decades there has the much increase in the number of universities both in public and 
private sectors. With this rapid growth the number of universities increased.

\section{Research Methodology}

The study was quantitative and non-experimental correlational design was used. The population of the study comprised of the 131 MPhil students and $26 \mathrm{PhD}$ students of the University of Haripur.

\section{Sample}

All 131 M.Phil and 26 Ph.D students of the population were selected as a sample of the study but response was received from 101 M.Phil and 05 Ph.D students. The detail of the 116 students who filled questionnaires is given in the following table.

\begin{tabular}{clrc}
\hline S.No & Department & M.Phil & Ph.D \\
\hline 1 & Education & 17 & 3 \\
2 & Agriculture & 21 & 10 \\
3 & Environmental & 14 & 2 \\
4 & Mathematics & 9 & 0 \\
5 & Forestry & 18 & 0 \\
6 & Management & 6 & 0 \\
7 & Microbiology & 16 & 0 \\
& Total & $\mathbf{1 0 1}$ & $\mathbf{1 5}$ \\
\hline
\end{tabular}

\section{Research Tool}

A questionnaire having 22 items was used for collection of data. The questionnaire organized into four sections. The first section of the questionnaire was about the social status of the scholar (age group, gender, marital Status and residence), the second section was about educational preferences and skills of scholar on a four point Likert scale (strongly agree, agree, disagree and strongly disagree), third section consist of the economic status of the scholars and the fourth section consist of expectations of the scholar on a five point Likert scale. The data from the concerned students of Ph.D and M.Phil from the University of Haripur was collected personally through the questionnaire. For data analysis, multiple regressions were computed by SPSS. Multiple regression was used as a set of variables were used each of which correlates to some extent with a criterion variable for which we like to predict values. The predictor variables are called independent variables and the criterion variable are called dependent variables in SPSS. 


\section{Findings / Results}

Table 1:

Model summary of university students' social status for their research expectations

\begin{tabular}{ccccc}
\hline Model & $\mathrm{R}$ & $\mathrm{R}$ Square & Adjusted R Square & Std. Error of the Estimate \\
\hline 1 & $.362^{\mathrm{a}}$ & .131 & .092 & 3.98985 \\
\hline
\end{tabular}

Table 1 indicated that an increase of one unit in university students' social status causes $13.1 \%$ increase in their research expectations at university.

Table 2:

Analysis of variance for university students' social status on their research expectations

\begin{tabular}{llccccc}
\hline & Model & Sum of Squares & $d f$ & Mean Square & $F$ & $P$ \\
\hline & Regression & 268.509 & 5 & 53.702 & 3.373 & $.007^{\mathrm{a}}$ \\
1 & $\begin{array}{l}\text { Residual } \\
\text { Total }\end{array}$ & 1782.915 & 112 & 15.919 & & \\
\hline
\end{tabular}

a. Predictors: (Constant), Age, gender, Marital status, Residence Haripur,

b. Dependent Variable: Research expectations

The results of ANOVA given in table 2 showed that is significant difference among mean scores of independent variables indicated by the $\mathrm{F}$ value $(\mathrm{F}=3.373, \mathrm{p}=0.007)$.

Table 3:

Effect of university students' social status on their research expectations

\begin{tabular}{|c|c|c|c|c|c|c|}
\hline & \multirow{2}{*}{ Model } & \multicolumn{2}{|c|}{$\begin{array}{l}\text { Unstandardized } \\
\text { Coefficients }\end{array}$} & \multirow{2}{*}{$\begin{array}{c}\text { Standardized } \\
\text { Coefficients } \\
\text { Beta }\end{array}$} & \multirow{2}{*}{$t$} & \multirow{2}{*}{$P$} \\
\hline & & B & $\begin{array}{l}\text { Std. } \\
\text { Error }\end{array}$ & & & \\
\hline \multirow{5}{*}{1} & (Constant) & 28.345 & 2.873 & & 9.867 & 0.000 \\
\hline & Age & -0.549 & 0.438 & -0.136 & -1.252 & 0.213 \\
\hline & Gender & -0.411 & 0.795 & -0.048 & -0.517 & 0.606 \\
\hline & $\begin{array}{l}\text { Marital } \\
\text { status }\end{array}$ & 1.477 & 1.023 & 0.151 & 1.444 & 0.151 \\
\hline & $\begin{array}{l}\text { Residence } \\
\text { Haripur }\end{array}$ & -2.255 & 0.818 & -0.249 & -2.755 & 0.007 \\
\hline
\end{tabular}


a. Dependent Variable: Research expectations

Table 3 explained the effect of university students' social status on their research expectations. Furthermore, the students who are resident of Haripur has significant negative effect on research expectations of students at university level as $(t=-2.755, \alpha=0.007)$ mean. The Rest of the factors of students' social status have no significant effect on research expectations of university students.

Table 4:

Model summary of university students' educational preferences and skills for their research expectations

\begin{tabular}{ccccc} 
Model & R & R Square & Adjusted R Square & Std. Error of the Estimate \\
\hline 1 & $.409^{\mathrm{a}}$ & .167 & .072 & 4.03383
\end{tabular}

Table 4 indicated an increase of one unit in university students' educational preferences and skillscauses $16.7 \%$ increase in their research expectations at university.

Table 5:

Analysis of variance for university students' educational preferences and skills on their research expectations

\begin{tabular}{llccccc}
\hline \multirow{2}{*}{ Model } & $\begin{array}{c}\text { Sum of } \\
\text { Squares }\end{array}$ & $d f$ & $\begin{array}{c}\text { Mean } \\
\text { Square }\end{array}$ & F & $P$ \\
\hline \multirow{2}{*}{1} & Regression & 342.882 & 12 & 28.574 & 1.756 & $.065^{\text {a }}$ \\
\cline { 3 - 5 } & $\begin{array}{l}\text { Residual } \\
\text { Total }\end{array}$ & 1708.542 & 105 & 16.272 & & \\
\hline
\end{tabular}

a. Predictors: (Constant), Graduate of the University of Haripur, Source of Information. personal Interest in higher education, personal interest in choosing in the University of Haripur, personal interest in course, computer skill, level of computer skill, time spend on reading, types of reading, preferences of reading.

\section{b. Dependent Variable: Research expectations}

The results of ANOVA given in table no 5 indicated that there is no significant difference among mean scores of independent variables as indicated by the $F$ value $(F=1.756, p=0.065)$. 
Table 6:

Effect of university students' educational preferences and skills on their research expectations

\begin{tabular}{lccccc}
\hline \multicolumn{1}{c}{ Model } & \multicolumn{2}{c}{ Unstandardized } & Standardized & & \\
& Coefficients & Coefficients & $t$ & $P$ \\
& B & Std. Error & Beta & & \\
\hline (Constant) & 28.852 & 3.244 & & 8.894 & .000 \\
Graduate UOH & -2.184 & .834 & -.251 & -2.619 & .010 \\
Source of info & .069 & .245 & .027 & .283 & .777 \\
Personal Interest H.Edu & .280 & .148 & .182 & 1.887 & .062 \\
Personal interest choose & .123 & .191 & .066 & .647 & .519 \\
UOH & .087 & .210 & .040 & .411 & .682 \\
Personal interest course & -.671 & .681 & -.093 & -.985 & .327 \\
Computer skill & -.328 & .503 & -.061 & -.653 & .515 \\
Level of computer skill & -.319 & .330 & -.091 & -.968 & .335 \\
Time spend on reading & .197 & .408 & .047 & .482 & .631 \\
Type of reading & -.074 & .349 & -.020 & -.211 & .833 \\
Preference of reading & & & & & \\
\hline
\end{tabular}

a. Dependent Variable: Research expectations

Table 6 explained the effect of university students' educational preferences and skills on their research expectations. Only graduate of the University of Haripur has significant negative effect on research expectations of students at university level as $(\mathrm{t}=-2.619, \alpha=0.010)$. The Rest of the factors of university students' educational preferences and skills have no significant effect on research expectations of university students.

Table 7:

Model summary of university students' economic status for their research expectations

\begin{tabular}{ccccc}
\hline Model & R & R Square & Adjusted R Square & Std. Error of the Estimate \\
\hline 1 & $.201^{\mathrm{a}}$ & .041 & .012 & 4.39885 \\
\hline
\end{tabular}

Table 7 indicated that an increase of one unit in university students' economic status causes $1.2 \%$ increase in their research expectations at university. 
Table 8:

Analysis of variance for university students' economic status on their research expectations

\begin{tabular}{llccccc}
\hline \multirow{2}{*}{ Model } & $\begin{array}{c}\text { Sum of } \\
\text { Squares }\end{array}$ & $d f$ & $\begin{array}{c}\text { Mean } \\
\text { Square }\end{array}$ & F & P \\
\hline \multirow{2}{*}{1} & Regression & 59.675 & 4 & 14.919 & .771 & $.548^{\text {a }}$ \\
& Residual & 1412.543 & 73 & 19.350 & & \\
& Total & 1472.218 & 77 & & & \\
\hline
\end{tabular}

a. Predictors: (Constant), Age, gender, Marital status, Residence Haripur,

b. Dependent Variable: Research expectations

The results of ANOVA given in table 8 indicated that is no significant difference among mean scores of independent variables as indicated by the $\mathrm{F}$ value $(\mathrm{F}=0.771, \mathrm{p}=0.548)$.

Table 9:

Effect of university students' economic status on their research expectations

\begin{tabular}{lccccc}
\hline \multicolumn{1}{c}{ Model } & \multicolumn{2}{c}{ Unstandardized } & \multicolumn{2}{c}{ Standardized } \\
& Coefficients & Coefficients & $t$ & $P$ \\
& $\mathrm{~B}$ & $\begin{array}{c}\text { Std. } \\
\text { Error }\end{array}$ & Beta & & \\
\hline (Constant) & 24.889 & 1.971 & & 12.630 & .000 \\
Job & -.532 & .939 & -.070 & -.566 & .573 \\
Nature of & .301 & .406 & .093 & .742 & .461 \\
1 job & & & & \\
Experience & -.297 & .401 & -.093 & -.741 & .461 \\
Income & 1.395 & 1.092 & .159 & 1.277 & .206 \\
\hline
\end{tabular}

a. Dependent Variable: Research expectations

Table 9 indicated that effect of university students' economic standard on their research expectations. Furthermore, none of the factors of university students' economic status have any significant effect on research expectations of university students.

\section{Conclusions and Discussion}

On the basis of finding 1, it was concluded that the independent variable was successfully regressed on the dependent variable the research scholar expectation of higher education at $\mathrm{UOH}$. The social status of graduates, as an independent variable, contributed in explaining 
the affection their research expectations in higher education. It is concluded that the non-resident of Haripur has more expectations for research of the host university. Result of the study were aligned with the Walker (2008) as it was suggested that more could be done institutionally and in classrooms to better align what teachers intend to teach and what students expect to learn.

On the basis of finding 2, it was concluded that the independent variable was regressed on the dependent variable the research scholar expectation of higher education at $\mathrm{UOH}$. The graduate other than $\mathrm{UOH}$ as an independent variable (educational preferences and skills) contributes the most in explaining more expectation for research [w5].Result of the study were in accordance with Ginns (2007) as it was concluded that students' perceptions of teaching quality in higher education may be increased if they have more opportunity to access and explore as their vision will broaden to expect more from universities.

On the basis of finding 3, it was concluded that the independent variable was successfully regressed on the dependent variable the research scholar expectation of higher education at $\mathrm{UOH}$. Economic status, as an independent variable does not contribute in explaining the effect on their research expectations in higher education. Result of the study were aligned with Byrne (2005) as it was found that students' motives, expectations are not with their economic status in higher education.

\section{Recommendations}

It may be suggested that the social status of graduates, such as where he resides contributed in their research expectations in higher education, in the formulation of eligibility criteria of any program in department expectation of a resident of the locality may be considered for making it effective.

It may be suggested that the graduate other than the university in educational preferences and skills may be addressed in explaining expectation such as by designing prospectus of each program, and by the interaction of different strategies in the teaching and learning process in the university.

It may be suggested that the economic status of the student may be attached with student learning opportunity available in the institute, the institute may provide student' to adopt positive mental attitude toward the society. 


\section{References}

Akareem, H. S., \& Hossain, S. S. (2012). Perception of education quality in private universities of Bangladesh: A study from students' perspective. Journal of Marketing for Higher Education, 22 (1), $11-33$.

Brennan, J., \& Teichler, U. (2008). The future of higher education and of higher education research. Higher Education, 56(3), 259-264.

Brew, A. \& Lucas, L. (2009). Academic research and researchers. Society for Research in Higher Education/Open University Press.

Briukhanov, V., Kiselev, V., Timchenko, N., \&Vdovin, V. (2010). Monitoring the opinions of parents of college students as a component of the institution's In-house education quality management system. Russian Education \& Society, 52(5), 79-88.

Byrne, M. \& Flood, B. (2005).A study of accounting students' motives, expectations and preparedness for higher education. Journal of Further and Higher Education, 29(2), 111 - 124.

Ginns, P., Prosser, M., \& Barrie, S. (2007). Students' perceptions of teaching quality in higher education: The perspective of currently enrolled students. Studies in Higher Education, 32(5), 603-615.

Hoodbhoy, P. (2009). Pakistan's higher education system - What went wrong and how to fix it, The Pakistan Development Review, 48(4), 581-594

[Online]

Available:http://pide.org.pk/pdr/index.php/pdr/article/viewFile/2643/ $2610 \mathrm{http} / / /$ ihelpf9.com/problems-and-solutions-of-higher-educationin-pakistan/

Mohanthy, J. (2000). Current trends in higher education. New Delhi, India: Deep \& Deep.

Rahman, A. U., \& Uddin, S. (2009). Statistical analysis of different socio economic factors affecting education of NWFP (Pakistan). Journal of Applied Quantitative Methods, 4(1), 88-94.

Rao, V. K. (2003). Higher education. New Delhi, India: A. P. H. Public Corporation. 
Semela, T. (2011). Breakneck expansion and quality assurance in Ethiopian higher education: Ideological Rationales and Economic Impediments. Higher Education Policy, 24, 399- 425. doi:10.1057/hep.2011.11

Sivakumar, M., \& Sarvalingam, A. (2010). Human deprivation index: A measure of multidimensional poverty. Available at https://mpra.ub.uni-muenchen.de/22337/1/MPRA_paper_22337.pdf

Voss, R., Gruber, T., \& Szmigin, I. (2007). Service quality in higher education: The role of student expectations. Journal of Business Research, 60, 949-959.

Walker, P. (2008). What do students think they (should) learn at college? Student perceptions of essential learning outcomes. Journal of the Scholarship of Teaching and Learning, 8(1), 45-60.

Wolff, S. (2002), Design Features for Project-Based Learning, Oregon State University. Corvallis: Oregon. [Online] Available at http://citeseerx.ist.psu.edu/viewdoc/download;jsessionid=FC401F43 26981DF33B0E53CBCDBC706C?doi=10.1.1.497.633\&rep=rep1\&t ype $=$ pdf

Citation of this Article:

Ayub, S., \& Khan, M.S. (2019). A critical analysis of research scholar expectation in higher education. Pakistan Journal of Education, 36(3), 39-50.

DOI: 10.30971/pje.v36i3.576.g194

To link this article:http://dx.doi.org/10.30971/pje.v36i3.576 